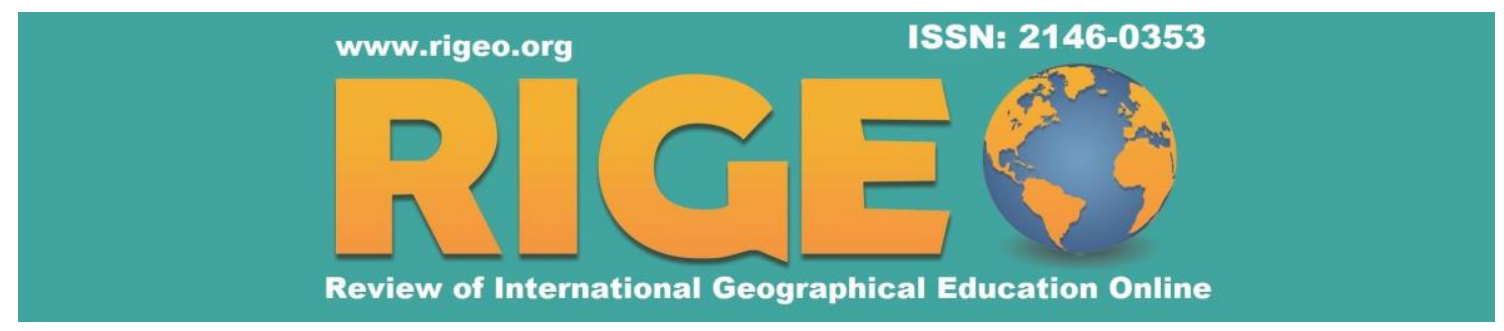

Review of International Geographical Education Online

(C) RIGEO Volume 8, Number 3, Winter 2018

Research Article

Copyright @ RIGEO 2018

To cite this article: Cin, M.; Değirmençay, Ş. A. (2018). Decision-Making of Middle School Students during an Earthquake. Review of International Geographical Education Online (RIGEO), 8(3), 556-570. Retrieved from http://www.rigeo.org/vol8no3/Number3winter/RIGEO-V8-N3-8.pdf

Submitted: May 24, $2018 \quad$ Revised: November 1, $2018 \quad$ Accepted: November 21, 2018

\title{
Decision-Making of Middle School Students during an Earthquake
}

\author{
Mustafa CíN ${ }^{1}$ \\ Giresun University, Giresun, TURKEY \\ Şerif Ali DEĞİRMENÇAY² \\ Giresun University, Giresun, TURKEY
}

\begin{abstract}
The foreknowledge of peoples' decision-making process during an earthquake may give important clues as to whether or not their decisions will yield secure results. In the context of earthquake education, drawing upon these clues can potentially minimize the loss of life during earthquakes to a certain extent. Thus, the aim of this study was to determine decision-making process of students during an earthquake. The research was carried out in Giresun, Turkey. One hundred twenty-two (122) eighth grade students from three middle schools were included the study as a sample base. Three decision trees were developed in order to understand students' decision process (es). Students gave their answers on the three decision trees, whereupon their answers were analyzed using descriptive statistics. The results of the study showed that some students during an earthquake chose secure options, whilst others preferred options that can lead to negative results. Students' desire to escape from their locations during an earthquake was found to be the most common, but also the most unsafe decision. A number of other students, however, had opted to take a dangerous protection position during an earthquake. It was concluded that excessive fear of earthquakes and the negative influence of the media both have an effect on making unsafe decisions. The study suggested that people ought to be assured that there is a low possibility of buildings completely collapsing during an earthquake. It also recommended that people should take non-structural rather than structural risks into consideration during an earthquake, and that they ought to base their make decisions according to these risks.
\end{abstract}

\section{Keywords}

Earthquake Education; Decision-making; Earthquake Preparedness; Earthquake Safety; Middle School

${ }^{1}$ Corresponding author: Prof. Dr. Giresun University, Faculty of Education, Department of Primary Education, Giresun,

Turkey, E-mail: mustafa.cin [at] giresun.edu.tr

2Assoc. Prof. Dr. Giresun University, Faculty of Education, Department of Mathematics and Science, Giresun, Turkey, E-mail: serifali.degirmencay [at] giresun.edu.tr

(C) Review of International Geographical Education Online

RIGEO 2018

ISSN: $2146-0353$

Www.rigeo.org 
People throughout their daily lives encounter hundreds of different situations and make countless decisions accordingly (e.g. decisions relating to health, career, education, and management, etc). Lahidji (2003) states that decision making ranges from decisions surrounding normal everyday event to extreme disasters such as natural or even man-made disasters. Decision making during disasters changes the dynamics involved with decision-making processes and, more often than not, creates situations of panic.

During everyday life decisions, people usually have time to think, benefit from their own and/or other people's experiences, and research what they are to do when they need to. In such cases, people can more or less estimate the results. However, sometimes people may need to make decisions under the pressure of time or in the case of an emergency (i.e. disasters). Withanaarachchi and Setunge (2014) indicate that all types of disasters can impact people, communities, and the environment, as well as a damage and/or destroy cities and critical infrastructure. Moreover, each disaster is different, and the decisions must suit the needs and requirements of the situation in question accordingly.

Earthquakes are one type of natural disaster that occur spontaneously and that can leave potentially harmful consequences in their wake. The moment of an earthquake is a high-risk situation that whereby people need to make correct decisions within an extremely short period of time. There are many studies that focus on the factors influencing decision making in risky situations. Kahneman \& Tversky (1979) had developed a descriptive model for the decision making process under risk, and suggested that problem framing can control individual decision-making in high-risk situations. In addition to problem framing, Sitkin \& Pablo (1992) identified eight key characteristics that influence decision-making, including risk preference, risk perception, risk propensity, group composition, cultural risk values, leader risk orientation, organizational control systems, and problem familiarity.

A large number of studies have been carried out regarding the decision-making patterns of people during various emergency scenarios such as earthquakes, flooding, forest fires, economic crises, and medication overdosage, etc. In parallel with the suggessitions put forth by both Kahneman \& Tversky (1979) and Sitkin \& Pablo's (1992), each of these studies have found that many factors influence the decisionmaking process in cases of emergency and uncertainty. A person's sense of risk perception (Sitkin \& Weingart 1995; Pennings \& Grossman, 2008), their past experiences during risk situtations, (Hammer \& Schmidlin 2002; Comstock \& Mallonee, 2005), as well as their personal characteristics (Lauriola, Levin \& Hart, 2007) all considerably affect their decision-making processes. It has also been observed that age, gender, socio-economic status (Silver, 2012), and media (Coleman, 1993; Silver, 2012) also influence personal decision-making processes to a certain degree. An indivdual's level of education in terms of their prior knowledge and understanding about emergency situation may also affect how they make decisions.

The level of adequacy of the preliminary information provided during an emergency is also considered to be an important factor that can affect decision-making. People tend 
to make decisions according to the preliminary information provided to them about the issue (Clore \& Huntsinger, 2007). Should the preliminary information in question be inadequate, they then instead resort to making decisions based on their emotions (Pham, 1998). Decisions made due to a lack of insufficient preliminary information can also lead to serious risks. Hence, determining how people make decisions using preliminary information can not only add a new dimension to studies regarding earthquake education, it may also contribute to reducing loss of life during an earthquake. Due to the importance of this, this study focuses on revealing school children's decisionmaking patterns during an earthquake, as well as on determining which factors are effective in these decisions.

Studies about earthquake education have been conducted in many countries around the world (Leather, 1987; Schoon, 1992; Ross \& Shuell, 1993; Sharp, Mackintoch \& Seedhouse, 1995, Dove, 1998; Tsai, 2001; Finnis et al., 2004; Libarkin et al., 2005; Johnston et al., 2011; Johnson \& Ronan, 2014; Izadkhah \& Gibbs, 2015; Mutch, 2015). The vast majority of these studies focus on the knowledge and attitudes held by students regarding earthquakes, the role of schools and teachers in reducing earthquake-related casualties, on the teaching methods, textbooks, and education programs employed as part of earthquake education. Studies focusing on similar issues have also been carried out in Turkey. What all of studies reveal is that students and adults were not adequately prepared for an earthquake, that their understanding of earthquakes varies, and that most are extremely fearful of earthquakes (Demirkaya, 2007; Cin, 2010; Kaya, 2010; Aksoy, 2013; Çoban, Sözbilir, \& Göktaş, 2017). Although many studies have been conducted within the scope of earthquake education, few studies exist determining students' decision-making patterns during earthquakes.

\section{Methodology}

\section{Participants}

Turkey is very much prone to earthquakes, and has faced several high magnitude earthquakes in the past. Although much of the country rests on an earthquake-prone belt, the city of Giresun is not prone to strong earthquakes. This study was carried out in Giresun, which is situated the north-eastern Turkey's Black Sea coastal region. One hundred twenty-two (122) eighth grade students attending three regional middle schools were randomly selected to participate in the study - of which include sixty-four (64) females and fifty-eight (58) males with a mean age of 14.22. All of the subjects reside in the either in or immediately surrounding the city centre, and all share similar socioeconomic traits. According to Turkey's national curriculum, students are expected to have acquired a fundamental knowledge about earthquakes and earthquake protection by grade 8 , meaning that topics related to earthquake protection are expected to be taught to the participants in previous classes in order to meet national requirements.

\section{Procedure}

The data was collected between April and May 2015 at the school where the study was conducted. Written approval in order to carry out the study was obtained from 
school administrators. The questionnaire form was filled out by the student participants, whereupon the data was collected by the researcher on site in the classroom. The completion of the questionnaire took about between 20 to 30 minutes.

\section{Data Collection Tools}

It was found that methods involving surveys, interviews, and document analysis have mostly been used as data collection tools in previous studies on earthquake education (Değirmençay \& Cin, 2016). Although each such tools have unique advantages and disadvantages, the choice as to which tool or tools will be used is made based on the purpose of the study. In this study, a questionnaire form was developed. The form included questions relating to the students' personal information, where they acquired their knowledge about earthquakes, and decision trees that measure their decisions during an earthquake.

A decision tree is a tree-like diagram that comprises of various interrelated options, allowing people to reach an accurate decision among these options. Studies have shown that decision trees are used as resource for teaching, decision analysis, measurement and evaluation, and data mining (Pauker \& Kassirer, 1987; Kaur \& Wasan, 2006; Çelen, 2013). Moreover, a number of other studies also reveal that decision trees can be used as a data collection tool (Fryer, 2006; Ezell et al., 2010).

Three decision trees were created in order to measure the decision-making of students during an earthquake, each looking at one of three possible scenarios: being caught in an earthquake in a classroom, in an apartment building (on the 3rd floor) and in an open area (a crowded environment), respectively. The first question gave students two options. Students who followed either one of the options had encountered a question at the second stage. Questions at third stage included three additional options, whereby students, in selecting one of the options, attempted to find the safest outcome during an earthquake, in their opinions. Questions were gradual, intercorrelated, and organized from general to specific (Appendix; Figures 1, 2, and 3).

\section{Validity and Reliability}

Questions on the scale as well as the related options were developed with the aim of measuring the students' decision making process during an earthquake. The relevant literature was scanned in detail in order to keep questions and options in line with the purpose and scope of this study. The draft scale was given to 32 students during the first stage. The scale's questions and options were revised in terms of language and content integrity through reviewing the students' answers. Some of the questions and items of the scale were thus changed according.

The reliability analysis of the scale was performed involving 49 students studying at a different school. In order to determine the level of reliability of the scale, an internal consistency coefficient was calculated using SPSS-Kuder-Richardson (KR-20). The KR-20 alpha value was calculated for the first, second, and third question groups as being $0.887,0.788$ and 0.730 , respectively. The mean alpha value of all three question groups was determined to be 0.801 . Given that the alpha coefficients of the entire scale and each question group were greater than 0.70 , the internal consistency coefficient of the scale was found to be adequate. 


\section{Data Analysis}

Data analysis was performed using descriptive statistics. After pairing students' answers with the decision tree questions, their percentages and frequencies were calculated. Each stage was then presented in tables by analysing the questions and answers one by one in order to show the details of the answers.

\section{Findings}

\section{Where Students Acquired Their Knowledge about Earthquakes From}

The scale included eight items in order to determine where students acquired their knowledge about earthquakes from. The frequency numbers were higher than the number of students because students were able to select more than one item. The frequencies are shown in Graphic 1.

The study revealed that students' learn about earthquakes from several sources. School courses were determined to be the largest information source - this, followed by media (e.g. internet, television, documentaries, films etc.), which emerged as being the second largest source of information.

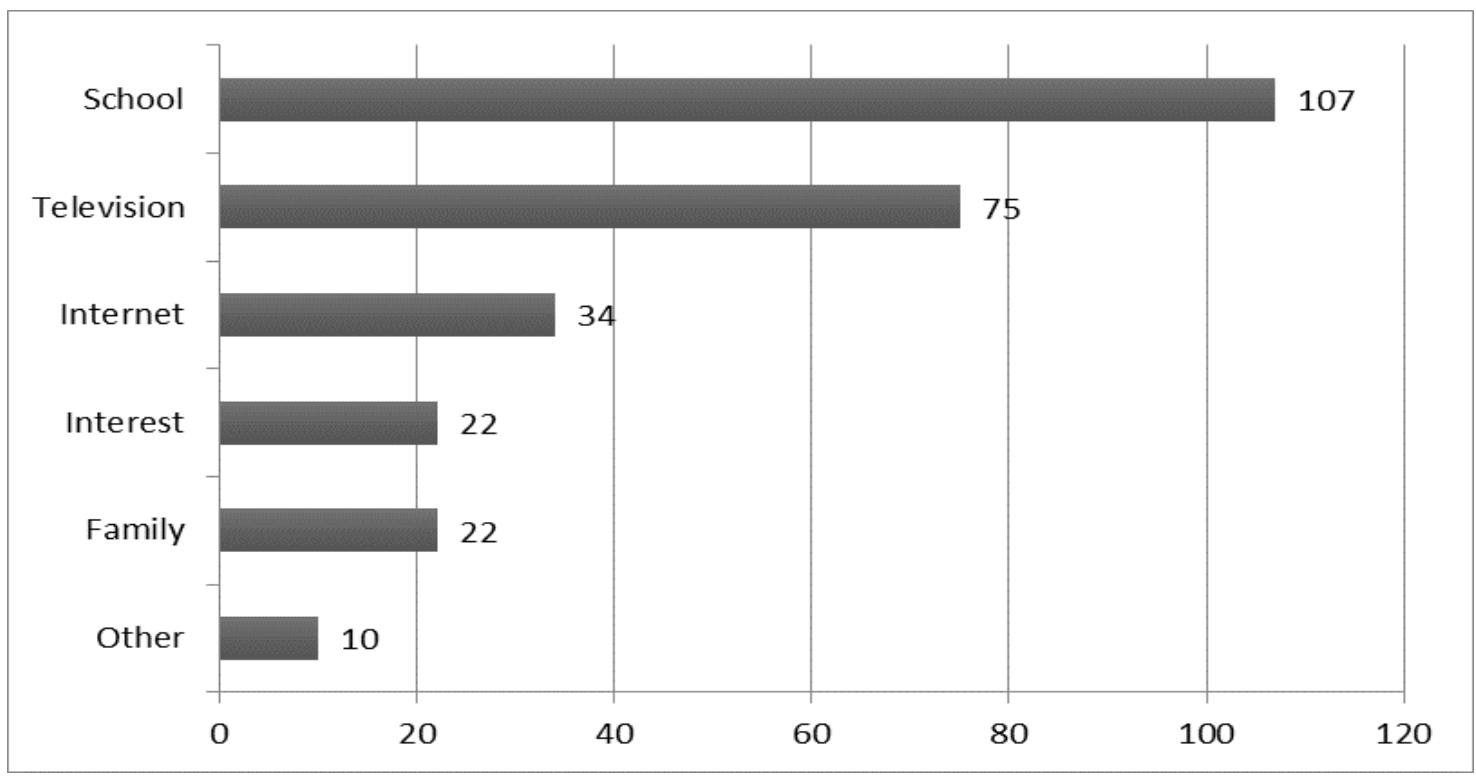

Graphic 1. Where Students Learn About Earthquakes From

The study also found that a relatively small handful student had obtained information about earthquakes either through discussions with their family members or by means of individual research. 


\section{Students' Approach to Decision-Making in the Event of an Earthquake whilst in a Classroom}

The first decision tree of the scale is as follows: "You are taking a class in the classroom. A severe earthquake occurs. What do you do?" Students' answers are shown in Table 1.

Table 1

The Decision-Making Process of Students in the Event of an Earthquake Whilst in a Classroom

\begin{tabular}{|c|c|c|c|c|c|}
\hline $\begin{array}{l}\text { Answers of } \\
\text { Students } \\
\text { (Stage I) }\end{array}$ & No & $\%$ & $\begin{array}{l}\text { Answers of Students } \\
\text { (Stage II) }\end{array}$ & No & $\%$ \\
\hline \multirow{3}{*}{$\begin{array}{l}\text { I would wait in the } \\
\text { classroom* }^{*}\end{array}$} & \multirow{3}{*}{62} & \multirow[t]{3}{*}{50.8} & $\begin{array}{l}\text { I would follow the drop-cover- } \\
\text { hold on method* }\end{array}$ & 53 & 43 \\
\hline & & & $\begin{array}{l}\text { I would use the triangle of life } \\
\text { method }\end{array}$ & 9 & 7.3 \\
\hline & & & $\begin{array}{l}\text { I would sit on the desk and } \\
\text { protect my head }\end{array}$ & 0 & 0 \\
\hline \multirow[t]{3}{*}{$\begin{array}{l}\text { I would run out of } \\
\text { the classroom }\end{array}$} & \multirow[t]{3}{*}{60} & \multirow[t]{3}{*}{49.2} & $\begin{array}{l}\text { I would wait in the garden or an } \\
\text { open area }\end{array}$ & 40 & 32.7 \\
\hline & & & $\begin{array}{l}\text { I would evacuate out into the } \\
\text { street }\end{array}$ & 18 & 14.7 \\
\hline & & & $\begin{array}{l}\text { I would crouch against the school } \\
\text { wall }\end{array}$ & 2 & 1.6 \\
\hline Total & 122 & 100 & & 122 & 100 \\
\hline
\end{tabular}

\section{Students' Approach to Decision-Making in the Event of an Earthquake whilst in an Apartment Building}

The second decision tree of the scale is as follows: "You are residing on the third floor of an apartment building. A severe earthquake occurs. What do you do?' Students' answers are shown in Table 2.

Table 2

The Decision-Making Process of Students in the Event of an Earthquake Whilst in an Apartment Building

\begin{tabular}{|c|c|c|c|c|c|}
\hline $\begin{array}{l}\text { Answers of } \\
\text { Students (Stage I) }\end{array}$ & No & $\%$ & $\begin{array}{l}\text { Answers of Students } \\
\text { (Stage II) }\end{array}$ & No & $\%$ \\
\hline I wouldn't attempt & 85 & 69.7 & $\begin{array}{l}\text { I would follow the drop-cover-hold on } \\
\text { method* }\end{array}$ & 65 & 53.2 \\
\hline $\begin{array}{l}\text { to leave the } \\
\text { building* }\end{array}$ & & & $\begin{array}{l}\text { I would use the triangle of life method } \\
\text { I would crouch against the interior wall of } \\
\text { a room }\end{array}$ & $\begin{array}{l}14 \\
6\end{array}$ & $\begin{array}{l}11.4 \\
4.9\end{array}$ \\
\hline $\begin{array}{l}\text { I would attempt to } \\
\text { leave the building }\end{array}$ & 37 & 30.03 & $\begin{array}{l}\text { I would evacuate the building via running } \\
\text { down the stairs } \\
\text { I would evacuate the building via elevator } \\
\text { I would evacuate the building via jumping } \\
\text { off a balcony }\end{array}$ & $\begin{array}{l}3 \\
3\end{array}$ & $\begin{array}{l}2.4 \\
2.4\end{array}$ \\
\hline
\end{tabular}


Cin, M.; Değirmençay, Ş. A (2018) / Decision-making of middle school students during an earthquake....

\begin{tabular}{lrrr}
\hline Total 122 & 100 & 122 & 100 \\
\hline *The acceptable decision & & \\
\hline
\end{tabular}

The study found that most of the students would make the decision to stay in the building during an earthquake. On the other hand, it was seen that one third of the students would make the decision to evacuate the building during an earthquake. A considerable amount of those preferring to stay in the building chose the drop-coverhold on method as a safe precaution. A small number of students emphasized that being protected near the bed using the triangle of life method and "crouching against the interior wall of a room" are safe precautions. A significant number of those who were of the opinion that evacuating the building during an earthquake was the right decision had felt that evacuating the building via the stairs is safe. Those who had chosen to leave the building had emphasized that leaving the building by elevator or by jumping off a balcony are safe.

\section{Students' Approach to Decision-Making in the Event of an Earthquake whilst in a Crowded Open Area}

The third decision tree followed the scale as follows: "You are in a crowded open area. A severe earthquake occurs. What do you do?" Table 3 shows the students' responses to this question.

Table 3

The Decision-Making Process of Students in the Event of an Earthquake Whilst in a Crowded Environment

\begin{tabular}{|c|c|c|c|c|c|}
\hline $\begin{array}{l}\text { Answers of } \\
\text { Students (I. Stage) }\end{array}$ & $\mathbf{N}$ & $\%$ & $\begin{array}{l}\text { Answers of Students } \\
\text { (II. Stage) }\end{array}$ & $\mathbf{N}$ & $\%$ \\
\hline \multirow[t]{3}{*}{ I would stay calm* } & 85 & 69.7 & $\begin{array}{l}\text { I would tell those around me not to } \\
\text { panic * }\end{array}$ & 40 & 32.7 \\
\hline & & & $\begin{array}{l}\text { I would get into the drop-cover-hold } \\
\text { on position }\end{array}$ & 37 & 30.3 \\
\hline & & & I would use the triangle of life method & 8 & 6.5 \\
\hline \multirow{3}{*}{$\begin{array}{l}\text { I would leave the } \\
\text { environment in a } \\
\text { hurry }\end{array}$} & & & I would run to a quieter place & 29 & 23.7 \\
\hline & 37 & 30.03 & $\begin{array}{l}\text { I would get evacuate the scene and run } \\
\text { to my house }\end{array}$ & 5 & 4 \\
\hline & & & I would evacuate out onto the street & 3 & 2.4 \\
\hline Total & 122 & 100 & & 122 & 100 \\
\hline
\end{tabular}

This table showed that two thirds of the students would stay calm, whilst one third would flee the environment in the case of an earthquake occurring in a crowded environment. Nearly half of those who were of the opinion about staying calm had stated that panicing is not helpful and they ought to calm those around them down. A considerable amount of the students preferred to stay calm, whereas a small number of students felt the drop-cover-hold on position and the fetal position to be safe, respectively. Those who chose to hurriedly leave the environment reported that running 
to a quieter place during an earthquake is safe. A small number of students felt escaping the environment and running home or out onto the street to be safe.

\section{Discussion}

What this study reveals is that students make different decisions during an earthquake, some of which lead to safe results, while others lead to unsafe results. More than half of the students chose security by preferring not to leave their current environment, by not panicing, and by protecting themselves using the drop-cover-hold on position. Despite this, a number of students had made dangerous decisions, opting to leave their current environment by using the stairs, elevator, or balcony in order to seek out a place where they can create a triangle of life.

Staying in the classroom during an earthquake is the right approach in terms of safety. It is almost impossible to run, walk, or even stand upright during major earthquakes. What is more, students attempting to leave the classroom can lead to the formation of a stampede. Students attempting to evacuate the classroom at the same time may become squashed in hallways or between doorways. In such cases, the stampede can cause more loss of life than the earthquake itself. Moreover, given the length of time that an earthquake lasts for, it is not possible for students to exit the classroom within a short period. Those who are in the hallways will also experience the earthquake. It also is not possible to evacuate from an apartment building from the third floor within the duration span of an earthquake. Given this, attempting to flee via balconies, stairways, and elevators can ultimately lead to death.

Students may logically wish to go outside during an earthquake for any number of reasons. One main reason would be their fear of the building collapsing around them. There are various studies illustrating that that Turkish students believe that earthquakes are destructive, terrible, and frightening event (Demirkaya, 2007; Aydın \& Coşkun, 2010; Kaya, 2010; Aksoy, 2013). Strong fears thus develop into the strong urge to escape during an earthquake (Gençöz, 1998). Media, which appears to be one of the most important sources of information for the participants, might only do more harm than good in terms of heightening their extreme fear of earthquakes. Genç (2008) states that soon after the Marmara Earthquake that struck Istanbul in 1999, the overwhelming volume of images showing the aftermath of the disaster (i.e. debris, dead and wounded victims, desperate survivors) is often conveyed to readers through the media. The fact both that earthquakes occur frequently in Turkey, as well as that the media frequently makes mention of the destructive effect of earthquakes may be one source of students' fears. The reason why the participants of this study opted to run away during an earthquake may be due to their fear of earthquakes.

A considerable number of those who did choose to escape thought that open areas are secure. For example, most of the students who chose the option "I would run out of the classroom" stated that waiting in an open area such as a garden is secure. Similarly, most of those who chose "I would leave the crowded and open area environment during an earthquake" had also considered evacuating to an open area as secure. Such a decision can in turn be explained by a person's fear-dependant escape instinct. 
Staying in the open area during an earthquake is the right approach in terms of safety. However, shifting from an indoor to an outdoor area during an earthquake has its risks. A mass exit from a crowded environment into an open area may lead to a stampede. Moreover, other obstacles such as traffic and objects that can fall or topple over from above as one evacuates. Those who opt to approach open areas must consider such problems. Nevertheless, staying where you are and getting into protection positions should be considered to be the right behavior during an earthquake.

This study also found that most of those who considered staying in their current locations in order to be secure during an earthquake preferred the drop-cover-hold on method. For example, those who selected "I would wait in the classroom during an earthquake" as a means of security had stated that this method is correct. Also, those who had opted not to leave their apartment building had stated that crouching into the drop-cover-hold on position beneath a table is also correct. A small number of students perceived any area where they can follow the triangle of life method to be secure.

In order to understand which of the two survival methods (drop-cover-hold on or the triangle of life) is safer, where the arguments stem from first needs to be examined.

The fire-fighter as well as founder of the American Rescue Team Doug Coop argues in favor of the triangle of life. Coop has voluntarily participated in search and rescue operations in many countries; however, he has yet to conduct adequate scientific research on the issue. Following the 1999 Istanbul earthquake, he further promotes the use of the triangle of life as a result of his experience and observations. He states that voids are created next to big furniture, and that a clear majority of people rescued from the wreckage after the Marmara Earthquake were found in these places (Coop, 2005). His suggestion, thus, is often quoted in the Turkish press.

On the other hand, the Federal Emergency Management Agency (FEMA) and the American Red Cross have both stated that the drop-cover-hold on method is a safer option (Lopes, 2004; FEMA, 2014). Petal (2004) supports the FEMA's opinion as well as emphasizes that it is possible to survive in the voids of life created within completely collapsed buildings; however, should the building be shaken to the brink of collapse, then people are unable remain in their initial location. Petal (2004) also states that in such scenarios it is not possible to hold onto heavy objects in places where the triangle of life is created. Even if that were possible, these objects will not stay where they are. Mahdavifar, Izadkhah \& Heshmati (2009) conducted a study comparing each of the two aforementioned methods and concluded that the former method is more secure.

It is known that a large proportion of loss of life and injuries that occur during earthquakes results from non-structural damage. Non-structural elements include all of the parts of a building minus its carrier system and other indoor components. Among these elements include lighting systems, windows, office equipment, furniture, and any objects that sit on shelves or hang on walls. Therefore, non-structural damages result from hard, bulky objects such as chandeliers (which fall from above) as well as furniture and major appliances that either topple over or whereby negligence thereof can lead to fires. 
It is an unfortunate fact that many buildings in Turkey are not earthquake resistant. However, even during a massive earthquake, only a small proportion of buildings collapse. Attempting to protect oneself using the triangle of life method in damaged, semi-collapsed buildings will not protect people non-structural elements. In this case, it can be stated that the drop-cover-hold on protection position is therefore safer.

According to our findings, it was found that most students preferred the drop-coverhold on position, which is ideally taught both in education programs and textbooks alike. It can be stated that students made their decisions in light of the information they have received in school. Analysis of where students obtain their earthquake information from points toward school. On the other hand, the study also found that a handful of students did prefer the triangle of life method-a decision which appears to be influenced by media outlets such as the Internet. Upon analyzing a number of Turkishlanguage websites, what is observed is that quite a considerable number of sites recommend this second method during an earthquake, hence potentially influencing students' decisioning.

\section{Conclusions and Recommendations}

This study assesses how students make decisions in the event of an earthquake whilst either in a classroom, an apartment building, or an open but crowded area. Half of the students felt that waiting in the classroom during an earthquake is a secure move, while the remaining half thought that evacuating the classroom is a better option. When it came to an apartment building scenario, two thirds of students had made the decision to stay in the apartment building, whilst one third had chosen to flee from the apartment building, respectively. Those who made the latter decision thought that they can use the stairs, whereas a small number of them thought that should exit the building by jumping off a balcony or via the elevator. In the event of being caught in an earthquake whilst in an open and crowded area, nearly one third of students stated that running away was the securest thing to do.

Students' deciding to run away from their present locations could be explained by their fear of the building collapsing. Therefore, the fact that only a small number of buildings completely collapse in even the most destructive of earthquakes in Turkey, most deaths and injuries in fact result from non-structural damage (e.g. toppled down or fallen objects, fires, etc.). Students should be taught that the risk of buildings completely collapsing is low.

It was also uncovered that students by-and-large preferred the drop-cover-hold on position-which, although secure, can be exaggerated in certain cases. For example, students tended to prefer this method even in open areas. This shows they fail to understand the logic behind this position. Students ought to be informed that this position is not applicable in all circumstances, but rather that it only provides protection in closed areas from falling debris.

Nevertheless, our research has also revealed that some students prefer places where they can create the triangle of life. Following the 1999 Istanbul earthquake, this method became widely discussed in the media, thus leading to a circulation of negative 
information about what to do in the event of an earthquake. The effects of this can be off sided by teaching students the logic as well as theoretical background behind the "triangle of life".

Some students stated that leaving the building by running down the stairs, taking the elevator, or jumping off a balcony is a secure move. It is necessary to teach students that these methods are not secure during an earthquake, including why they are not secure.

The study found that the information that students receive from school is tremendously important. The training that schools provide will largely rectify any misconceptions that students may have when it comes decision making during a disaster. Facilitating both theoretical and applied education will help students understand the truth behind these misconceptions. Applied teaching methods, moreover, will not only integrate application and theory, but will also increase the chance that these behaviors become permanent and automatic.

One limitation of this study is that it is limited to only one region of Turkey. Carrying out similar studies in other regions of Turkey, and even in other countries, as well as comparing and contrasting the results will make a significant contribution to earthquake education. Another limitation is that it involved participants who were around 14 years of age. Further studies ought to be conducted both in various regions as well as with people of different age groups in order to better identify the similarities and differences of people's decision-making patterns in the event of earthquakes and other natural disasters, which can in turn play a significant role in reducing-if not preventing-loss of life.

\section{Acknowledgements}

This work is a part of the research program (numbered EGT-BAP-A-250414-69) which is supported by the Giresun University Scientific Research Commission.

\section{References}

Aksoy, B. (2013). Qualitative survey of perception of 9th graders who experienced an earthquake towards the concept earthquake. Journal of World of Turks, 15(1), 247-265.

Aydın, F. \& Coşkun, M. (2010). Observation of the students' "earthquake" perceptions by means of phenomenographic analysis (primary education 7th grade-Turkey). International Journal of the Physical Sciences, 5(8), 1324-1330.

Cin, M. (2010). Prospective classroom teachers' misconceptions about natural hazards. Marmara Geographical Review, 22, 70-81 (in Turkish).

Clore, G. L. \& Huntsinger, J.R. (2007). How emotions inform judgment and regulate thought. Trends in Cognitive Science, 11, 393-399.

Coleman, C.L. (1993). The influence of mass media and interpersonal communication on societal and personal risk judgments. Communication Research, 20(4), 611-624.

Comstock, R.D. \& Mallonee, S. (2005). Comparing reactions to two severe tornadoes in one Oklahoma community. Disasters, 29(3), 277-287.

Coop, D. (2005). Triangle of life. Protea Magazine, 1, 19-20.

Çelen, Ü. (2013). Psychometric properties of diagnostic branched tree. Education and Science, 
39(174), 201-213 (in Turkish).

Çoban, M., Sözbilir, M. \& Göktaş, Y. (2017). Determining preparation perceptions before earthquake of individuals experienced earthquake: A case study. Coğrafya Dergisi, 22(37), 113-134. (in Turkish).

Değirmençay, Ş.A. \& Cin. M. (2016). Earthquake education researches in Turkey: A descriptive content analysis. YYU Journal of Education Faculty, 13(1), 301-313 (in Turkish).

Demirkaya, H. (2007). Examining the earthquake attitudes of 5. 6. and 7. grade primary school students according to various variables. Turkish Journal of Social Research, 11(3), 37-51 (in Turkish).

Dove, J.E. (1998). Students' alternative conceptions in Earth science: a review of research and implications for teaching and learning. Research Papers in Education, 13(2), 183-20.

Ezell, B.C., Bennett, S.P., Winterfeldt, D. V., Sokolowski, J. \& Collins, A.J. (2010). Probabilistic risk analysis and terrorism risk. Risk Analysis, 30(4), 575-589.

FEMA, (2014). Drop, Cover, and Hold On. Poster, [online], Retrieved from URL: http://www.fema.gov/media-library/assets/documents/3266.

Finnis, K., Standring, S., Johnston, D. \& Ronan, K. (2004). Children's understanding of natural hazards in Christchurch, New Zealand. The Australia Journal of Emergency Management, 19(2), 11-20.

Fryer, M., Collins, C.D., Ferrier, H., Colvile, R.N. \& Nieuwenhuijsen, M.J. (2006). Human exposure modelling for chemical risk assessment: a review of current approaches and research and policy implications. Environmental Science \& Policy, 9(3), 261-274.

Genç F.N. (2008). Kriz iletişimi: Marmara Depremi örneği. Selçuk İletişim, 5(3), 161-75.

Gençöz, T. (1998). Fear: causes, consequences, and ways of coping. Journal of Crisis, 6(2), 916 (in Turkish).

Hammer, B. \& Schmidlin, T.W. (2002). Response to warnings during the 3 May 1999 Oklahoma City Tornado: reasons and relative injury rates. Weather and Forecasting, 17, 577-581.

Izadkhah, Y.O. \& Gibbs, L. (2015). A study of preschoolers' perceptions of earthquakes through drawing. International Journal of Disaster Risk Reduction, 14, 132-139.

Johnson, V.A. \& Ronan, K.R. (2014). Classroom responses of New Zealand school teachers following the 2011 Christchurch earthquake. Natural Hazards, 72, 1075-1092.

Johnston, D., Tarrant, R., Tipler, K., Coomer, M. \& Ruth, S.P. (2011). Preparing schools for future earthquakes in New Zealand: lessons from an evaluation of a Wellington school exercise. Australian Journal of Emergency Management, 26(1), 24-30.

Kahneman D. \&Tversky A. (1979). Prospect theory: an analysis of decision under risk. Ecibinetruca, 47: 263-291.

Kaur, H., \& Wasan, S.K. (2006). Empirical study on applications of data mining techniques in healthcare. Journal of Computer Science, 2(2), 194-200.

Kaya, M. (2010). Metaphors developed by secondary school students towards "earthquake" concept. Educational Research and Review, 5(11), 712-718.

Lahidji, R. (2003, September 15). Lessons learned in dealing with large-scale disasters. Washington, D.C.: Organization for Economic Co-operation and Development. 
Cin, M.; Değirmençay, Ş. A (2018) / Decision-making of middle school students during an earthquake....

Leather, A. D. (1987). Views of the nature and origin of earthquakes and oil held by eleven to seventeen year olds. Geology Teaching, 12(3), 102-8.

Libarkin, J., Anderson, S., Dahl, J., Beilfuss, M. \& Boone, W. (2005). Qualitative analysis of college students' ideas about the Earth: Interviews and open-ended questionnaires. Journal of Geoscience Education, 52(1), 17-26.

Lauriola, M., Levin, I.B., and Hart, S.S. (2007). Common and distinct factors in decision making under ambiguity and risk: A psychometric study of individual differences. Organizational Behavior and Human Decision Processes, 104, 130-149.

Lopes, R. (2004). Response to the Triangle of Life, [online] Retrieved from http://www.ocde.us/Emergency/Documents/9tri_of_life.pdf .

Mahdavifar, M.R., Izadkhah, Y.O. \& Heshmati, V. (2009). Appropriate and correct reactions during earthquakes: "drop, cover and hold on" or "triangle of life. Journal of Seismology and Earthquake Engineering, 11(1), 41-48.

Mutch, C. (2015). The role of schools in disaster settings: Learning from the 2010-2011 New Zealand earthquakes. International Journal of Educational Development, 41, 283-291.

Pauker, S.G. \& Kassirer, J.P. (1987). Decision analysis. The New England Journal of Medicine, 316:250-258.

Pennings, J.M.E. \& Grossman, D.B. (2008). Responding to crises and disasters: the role of risk attitudes and risk perceptions. Disasters, 32(2), 434-448.

Petal, M. (2004). Douglas Copp-Worse than urban legend: Dangerous advice! and now for some good advice for earthquake safety, [online] Retrieved from http://www.earthquakecountry.org/dropcoverholdon/Petal_on_Copp.pdf.

Pham, M. T. (1998). Representativeness, relevance, and the use of feelings in decision making. Journal of Consumer Research, 25, 144-159.

Ross, K.E.K. \& Shuell, T.J. (1993). Children's beliefs about earthquakes. Science Education, 11(2), 191-205.

Sharp, J. G., Mackintoch, M. A. P. \& Seedhouse, P. (1995). Some comments on children's ideas about Earth structure, volcanoes, earthquakes and plates. Teaching Earth Sciences, 20(1):28-30.

Schoon, K. J. (1992). Students' alternative conceptions of Earth and Space. Journal of Geological Education, 40(3), 209-214.

Silver, A. (2012). Factors influencing individuals' decision-making during high-risk shortnotice disasters: the case study of the August 21st, 2011 Goderich, Ontario tornado, (unpublished Master of dissertation), University of Waterloo, Canada.

Sitkin, S.B. \& Weingart, L.R. (1995). Determinants of risky decision-making behavior: A test of the mediating role of risk perceptions and propensity. The Academy of Management Journal, 38(6), 1573-1592.

Sitkin, S.B. \& Pablo, A.L. (1992). Reconceptualizing the determinants of risk behavior. The Academy of Management Review, 17(1), 9-38.

Tsai, C. (2001). Ideas about earthquakes after experiencing a natural disaster in Taiwan: An analysis of students' worldviews. International Journal of Science Education, 23(109), 1007-1016. 
Withanaarachchi, J. \& Setunge, S. (2014). Influence of decision making during disasters and how it impacts a community. Paper presented at 10th International Conference of the International Institute for Infrastructure Resilience and Reconstruction (I3R2). 20-22 May 2014 Purdue University, West Lafayette, Indiana, USA.

\section{Biographical statements}

Mustafa CÍN is a professor of geography education at Giresun University in Turkey. His research focuses on natural disaster education, earthquake education, environmental education and concept teaching and learning in geography.

Şerif Ali DEĞİRMENÇAY is an assistant professor in the Department of Turkish and Science Education at Giresun University in Turkey. His research interests focus on physics education and science education.

\section{Appendix}

\section{Data Collection Tools}

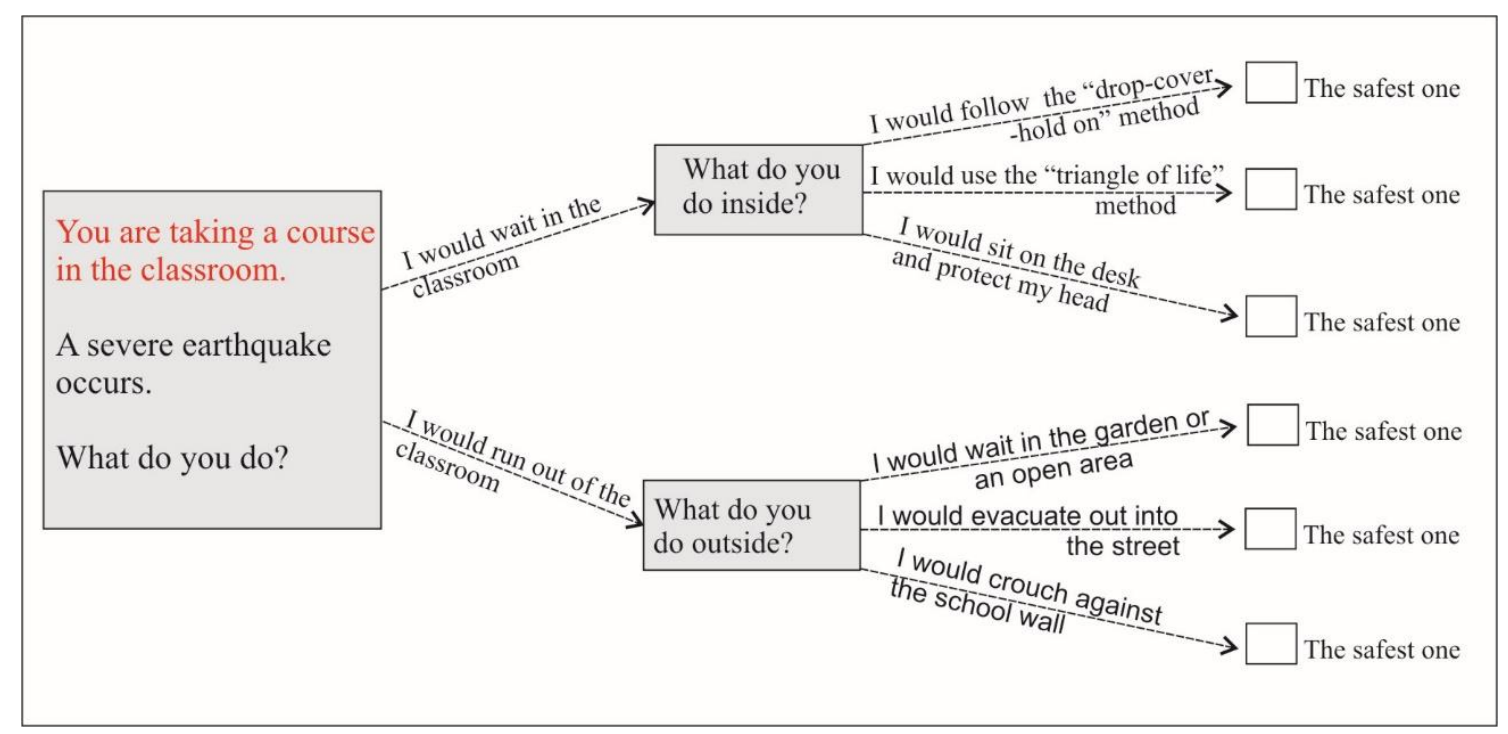

Figure 1. Decision tree of the scale related to a classroom environment 


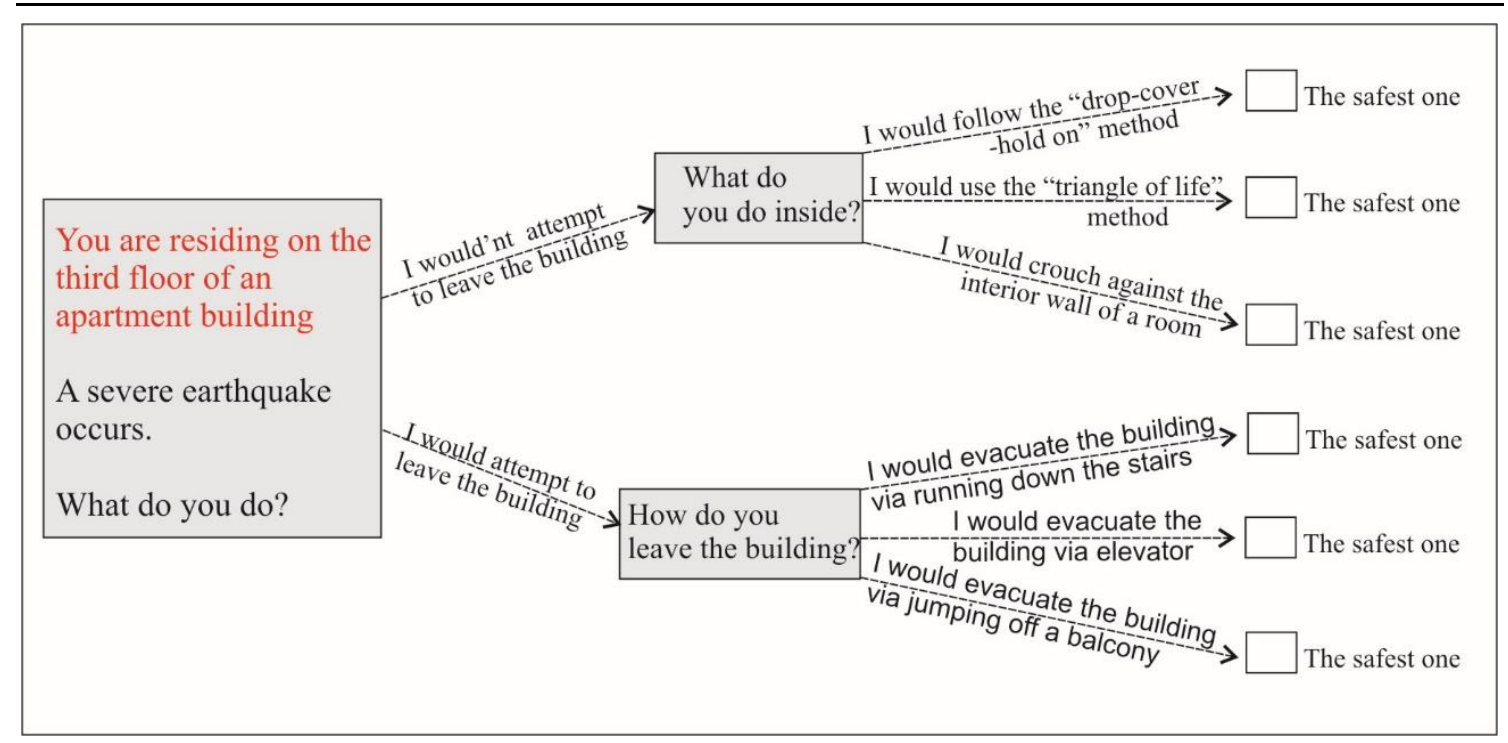

Figure 2. Decision tree of the scale related to an apartment building

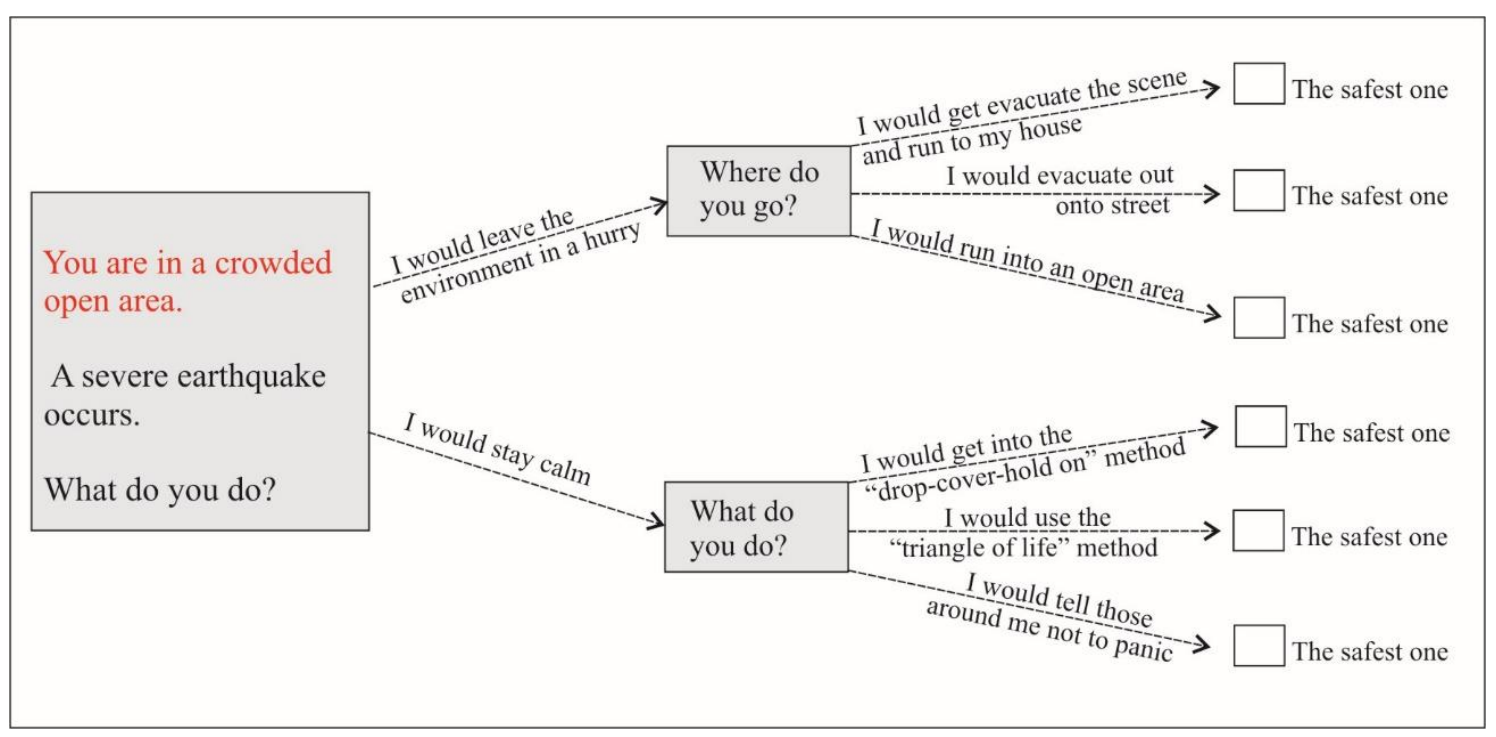

Figure 3. Decision tree of the scale related to a crowded environment in an open area 